\title{
The role of the pre-Alpine polycrystalline basement in the paleogeographic configuration of multiple Neotethyan oceanic basins
}

\section{Vloga predalpidske polikristalinske podlage pri paleogeografski razporeditvi oceanskih bazenov Neotetide}

\author{
Darko SPAHIĆ ${ }^{1} \&$ Tivadar GAUDENYI ${ }^{2}$
}

\author{
${ }^{1}$ Geological Survey of Serbia, Rovinjska 12, 11000 Belgrade, Serbia; \\ e-mail: darkogeo2002@hotmail.com; darko.spahic@gzs.gov.rs \\ ${ }^{2}$ Serbian Academy of Sciences and Arts - Geographical Institute "Jovan Cvijic", Djure Jaksica 9, \\ 11000 Belgrade, Serbia
}

Prejeto / Received 9. 2. 2021; Sprejeto / Accepted 25. 11. 2021; Objavljeno na spletu / Published online 28. 12.2021

Key words: Dinaric-Hellenic orogen, paleocontinental inheritance, "Drina-Pelagonide continental splinter", Pelagonides, Inner Dinaric-(Mirdita-Pindos) ocean, Drina-Ivanjica block, Neotethyan ophiolites

\begin{abstract}
The study provides a deeper understanding of the early Mesozoic paleogeogeographic spatial-temporal relationship by studying the two Adria-Europe intervening basement blocks. The Drina-Ivanjica and Pelagonian crustal fragments play important role in the internal early Alpine oceanic constitution further controlling the late Jurassic emplacement of Tethyan Dinaric-Hellenic ophiolites. The proposed paleogeographic reassessment is driven by the new paleocontinental inheritance data associated with the Variscan - pre-Variscan basement terranes. The recently published data suggest an Avalonian-type inheritance of the Pelagonian basement block which indicates a different pre-Variscan plate-tectonic journey, including separate spatial arrangement during Variscan amalgamation. In turn, Cadomian-type basement inheritance has been documented within the sliced Adria microplate. Thus, the Avalonian inheritance place the Pelagonian block away from the Apulia/ Adria (Dinarides). In the investigated context of Paleozoic-Mesozoic paleogeographic transition, the Pelagonian block may represent a segment of the Cimmerian ribbon continent or southernmost segment of the Variscan Europe. With regards the nearby Adria microplate, a Triassic-Jurassic oceanic opening led to the decoupling (spreading away from the main Adria microplate) of the Drina-Ivanjica block. The rifting is in line with the simultaneous yet opposite or westward-directed drift of the Pelagonides. The breakup of south European Variscan configuration eventually result in the spatial alignment of the two basement fragments referred to as the "Drina-Pelagonide continental splinter". By linking the paleogeographic pre-Jurassic-Jurassic relationship between these continental units, the two landlocked Neotethyan Vardar s.l. basins are extrapolated, "Dinaric Tethys" / Inner Dinaric-(Mirdita-Pindos) and the main Vardar Ocean (Western Vardar Zone).
\end{abstract}

\section{Izvleček}

Študija prinaša globlje razumevanje zgodnjemezozojskih paleogeogeografskih prostorsko-časovnih odnosov s preučevanjem razlik v podlagi dveh kontinentalnih blokov med Jadransko in Evropsko ploščo. Fragmenta skorje Drina-Ivanjica in Pelagonija sta igrala pomembno vlogo v notranji zgradbi zgodnjealpidskega oceana, kar je vplivalo tudi na narivanje dinarsko-helenskih ofiolitov $\mathrm{v}$ zgornji juri. $\mathrm{K}$ ponovnemu razmisleku o paleogeografiji so nas spodbudili novi podatki o značilnostih variskične in predvariskične podlage. Nedavno objavljeni podatki kažejo, da ima Pelagonijski blok podlago avalonijskega tipa, pri Jadranski mikroplošči in njenih fragmentih pa je bil dokumentiran kadomijski tip podlage. Razlike kažejo na različno predvariskično potovanje obeh kontinentalnih blokov in tudi ločeno prostorsko razporeditev med variskično amalgamacijo. Avalonijska preteklost uvršča Pelagonijski blok stran od Apulijske ali Jadranske plošče oziroma Dinaridov. Na prehodu iz paleozoika v mezozoik je bil Pelagonijski blok lahko del Kimerijskega kontinentalnega pasu ali najjužnejši del variskične Evrope. Na bližnji Jadranski mikroplošči je triasno-jursko odpiranje oceana privedlo do ločitve bloka Drina-Ivanjica in njegovega odmika na vzhod od glavne Jadranske mikroplošče. Rifting se ujema s hkratnim drsenjem Pelagonidov v nasprotni smeri, proti zahodu. Razpad južnoevropske variskične konfiguracije je lahko privedel do prostorske poravnave obeh blokov s skupnim imenom Drina-Pelagonija. Z upoštevanjem medsebojnega paleogeografskega položaja kontinentalnih enot pred juro in tekom jure lahko sklepamo, da sta v Neotetidi obstajala dva Vardarska bazena - Dinarska Tetida (Notranji Dinaridi-MirditaPindos) in glavni Vardarski ocean (Zahodna Vardarska cona). 


\section{Introduction}

The intriguing lithospheric elements of the Jurassic-earliest Cretaceous paleoceanography in the area of Western Balkan countries (Fig. 1a) underwent final suturing and collisional thrust stacking during the late Mesozoic - Paleogene (e.g., Picha, 2002; Csontos \& Vörös, 2004; Schmid et al., 2008; Xypolias et al., 2008; Robertson, 2012; Jolivet et al., 2016; Fig. 1b, c). Due to the exceptional exposure of the Jurassic ophiolite belts, a considerably large cluster of papers discusses important aspects of the exhumed Neotethyan oceanic lithosphere and associated depositional environments (e.g., Bernoulli \& Jenkyns, 1974; Dilek et al., 2005, 2007; Saccani et al., 2015, 2017, Tremblay et al., 2015; Dilek \& Furnes, 2017; Spahić \& Gaudenyi, $2020 \mathrm{c}$ and many others). The opening pattern of these landlocked oceans indicates the complex Permian-Triassic architecture of the intervening exotic Variscan peri-Gondwana terranes (including Adria as a Paleozoic continuation of the Austrian Alps; Pamić \& Jurković, 2002). These poorly understood continental lithosphere fragments (e.g., Vavvasis et al., 2000; Spahić \& Gaudenyi, 2020a, 2020b) represent a segment of the remobilized basement of the Alpine orogen.

The Permian-Triassic Pangea southern margin underwent extensional processes followed by the dispersal of this segment of the Supercontinent (Pamić \& Jurković, 2002; Spahić et al., 2020 and references therein). During the Ladinian/Carnian, this southern margin (Greece) was further affected by the poorly constrained Eocimmerian or Minoan terrane low-magnitude "docking" (Mountrakis, 1986; Zulauf et al., 2015; see Neubauer et al., 2019, for a discussion). The complicated processes of crustal weakening, dismemberment of the Triassic continental margin (rollback, rifting, and sea - floor spreading) are also documented within the considerably large Permian-Triassic Adria microplate (e.g., Pamić et al., 1998; Goričan et al., 1999; Dimitrijević, 2001; Dimitrijević et al., 2003). The most complex area is the northeastern tip of the Adria leading edge referred to as the Drina-Ivanjica block (Đoković, 1985; Spahić et al., 2018). This block has a striking N-S alignment with the Pelagonian block of the Hellenides (Figs. 1c and 2a). This elongated seemingly amalgamated paleoceanic splinter assembly comprises a dominantly Neoproterozoic - Paleozoic crystalline continental crust that separate the two Mesozoic ophiolite belts of Tethyan relevance. However, the definition of this "Drina-Pelagonian continental splinter" and its importance in the opening of Mesozoic Tethyan oceans remains poorly constrained (Mountrakis, 1986; Anders et al., 2007; Zlatkin et al., 2014, 2017; Spahić et al., 2019a and references therein; Figs. 1b, c). Although the majority of recent publications advocate a 'single ocean model' (e.g., Schmid et al., 2008; see discussion in Robertson et al., 2009; Handy et al., 2015; Jolivet et al., 2016; Maffione \& van Hinsbergen, 2018), the past position and the role of the "Drina-Pelagonian continental splinter" during the Triassic oceanization and latest Jurassic - early Cretaceous Vardar oceanic ophiolite obduction remains unanswered (also in Ferrière et al., 2012).

With a goal to go step forward in contributing the still open issue of the number of Tethyan oceans, the following study focuses on the Pelagonian (Fig. 2a) and Drina-Ivanjica role (Fig. 2b) in the Neotethyan evolution. By applying the update on the pre-Mesozoic paleogeographic inferences (detrital zircon analyses of the Pelagonian block) we pinpoint the principal differences between two basement units (see Žák et al., 2020, for the detrital zircon methodology). The two basement entities are traced during theirs Paleozoic paleogeographic journey that provided the input for reconstructing their position during Neotethyan Vardar Ocean opening and closure. The comparison shows that the Cadomian-type Adria terrane (its NE margin, Drina-Ivanjica block; available detrital zircon data from the nearby Austroalpine basement; Siegesmund et al., 2018) and Avalonian- (Zlatkin et al., 2014, 2017) Pelagonian basement are two discrete microplates. We also introduce the scarce Variscan - Eocimmerian Paleotethyan inferences with a goal to separate the two underlying continental crust segments (prior to Late Jurassic-earliest Cretaceous obduction-related oceanic closure events).

\section{Regional setting}

The complex allochtonous configuration of the Dinaric-Hellenic belt (e.g., Dimitrijević, 1997; 2001; Karamata, 2006; Xypolias et al., 2008; Schmid et al., 2008, 2020) underwent a long-term history of oceanic embayment, terrane drifting, accretion and collision since Neoproterozoic (e.g., "Paleo-Adria"; Franke et al., 2017; Spahić et al., 2018). In the Mesozoic framework, the Dinaric- and Vardar Zone ophiolite-bearing N-NW to S-SE-trending parallel crustal segments (Fig. 1b) representing the vestiges composed of highly heterogeneous ophiolitic mélanges (Fig. 2). The Dinaric-Hellenic mélanges are consisting of magmatic blocks and a variety of associated sedimentary rocks (Dimitrijević \& Dimitrijević, 


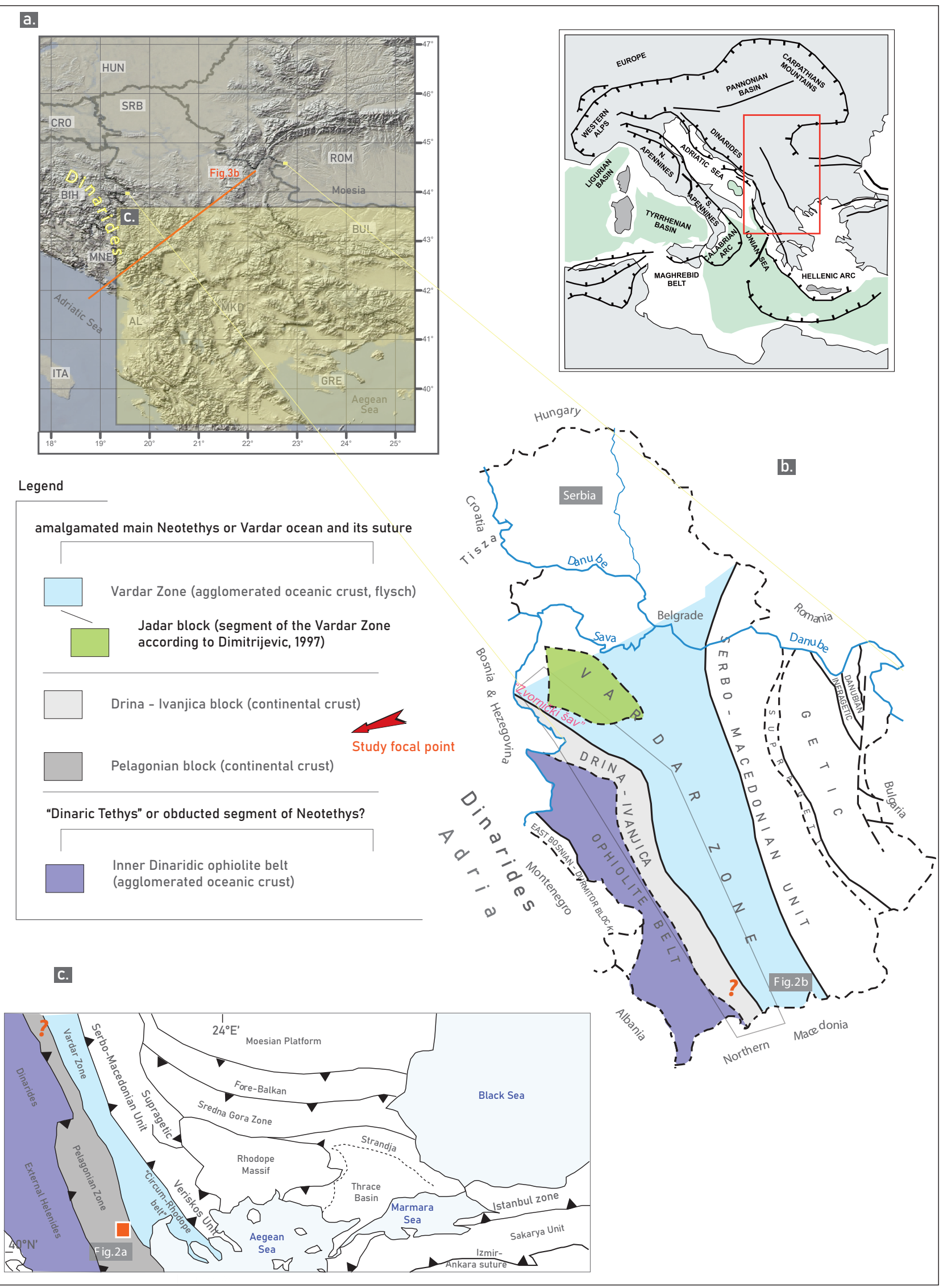

Fig. 1. a. Regional relief map including the countries of former Yugoslavia: SRB-Serbia, MNE-Montenegro, CRO-Croatia, BiH-Bosnia \& Herzegovina, MKD-North Macedonia, SLO-Slovenia, HUN-Hungary, ROM-Romania, BUL-Bulgaria, ALAlbania; b. Tectonic sketch map of Serbia (according to concept of Dimitrijević, 1992, map taken from Protić, 1995, also in Dimitrijević, 1997). The main tectonic units are written in the sketch. The Drina-Ivanjica block separating the two-ophiolite belts: to the SW is the Inner Dinaric Ophiolite Belt and to the NE is the Vardar Zone. c. Sketch map of major tectonic elements in the southern Balkan Peninsula and northern Greece (modified after Xypolias et al. 2008 and references therein). The Pelagonian block is thrust over the ophiolite-decorated External Hellenides. Red question mark emphasizes the investigated connection between the Drina-Ivanjica and the Pelagonian block. 
1973). The deformation of the mélange belts however varies (Dimitrijević \& Dimitrijević, 1975). The prominent ophiolite belt continues to the east-southeast along the Mirdita, Subpelagonian/Pelagonian - Inner Dinaridic Ophiolite Belt zones of the Albanides (e.g., Nance, 1981; Robertson \& Karamata, 1994; Dilek et al., 2005, 2007; Saccani et al., 2008; 2011, 2017; Gaggero et al., 2009; Tremblay et al., 2015). Another branch of these ophiolite belts are extending towards to the south in North Macedonia and Greece. Structurally these southern ophiolite belts are belonging to the external section of the Inner Hellenides and most internal segment of the Inner Hellenides (Fig. 1c).

Depending of the chosen paleogeographic model (sensu Bernoulli \& Laubcher, 1972; adopted by Schmid et al., 2008 among many others or 'multiple oceans model', see Spahić \& Gaudenyi, 2020, for a discussion; Fig. 3a), ophiolites of similar age are distributed on both sides of the continental splinter: westwards of the intervening the Drina-Ivanjica block and spreading across the Vardar Zone s.s. and the Albanides-Hellenides (Fig. 1c; see Fig. 1 of Faul et al., 2014). By applying 'single ocean model', the oceanic crust above the Drina-Ivanjica fragment is presumably offscraped after the out-of-sequence Cretaceous - Paleogene thrusting, further affected by the protracted surface exposure (Schmid et al., 2008, 2020; Figs. 3a, b). The compositions of these outcropping oceanic massifs ranges from Jurassic SSZ type-ophiolites formed along the entire length of the Dinarides towards in Albania, and Greece (ranges from $1200 \mathrm{~km}$ ). The subcontinental Inner Dinarides to depleted mid-ocean ridge/ arc compositions have often been documented within the Vardar Zone s.s. (to the east of the Drina-Ivanjica block; Fig. 1c).

The Paleozoic configuration of the amalgamated early Alpine Central European terranes (southern Laurussia in the Late Paleozoic framework and slightly postdating Eurasia) was controlled by the recurring Neoproterozoic - Lower to Middle Paleozoic plate-tectonic interplay between the fragmented peri-Gondwanan exotic terrane agglomerations and a fragmented south Euroasian foreland (e.g., Avigad et al., 2016; Zlatkin et al., 2014, 2017; Siegesmund et al., 2018; Spahić \& Gaudenyi, 2019a). The early Pan-African to Lower Paleozoic peri-Gondwanan arc interval (Kearey et al., 2009 and references therein) was followed by the late Variscan Paleotethyan closure and assembly of the southern realm of European Pangea (e.g., Stampfli \& Kozur, 2006;
Kroner \& Romer, 2013; Zulauf et al., 2018; Spahić et al., 2019a). The Middle Paleozoic spreading culminated during Variscan crustal thickening event best recorded along the western Moesian microplate (Iancu et al., 2005; Plissart et al., 2018; Spahić et al., 2019b; Šster et al., 2020). The Paleotethyan subduction outlived the Variscan event (Pamić \& Jurković, 2002; Spahić et al., 2019a), whereas the closure of Paleotethys itself is attributed to the poorly understood Triassic Eocimmerian "docking" (Zulauf et al., 2015). The Eocimmerian "docking" in the region seems to be controlled by the Triassic tectonic interaction among the North African ribbon continent (Stampfli et al., 2001), involving predominantly Cadomian-(Minoan) type crystalline fragments (Zulauf et al., 2015; Spahić et al., 2018; Šoster et al., 2020).

\section{Geology of Pelagonides and Drina-Ivanjica block}

The Pelagonian basement agglomeration is characterized by several magmatic and sedimentary sequences of different age displaced by the Alpine convergence. The Pelagonian nappestacked configuration is as follows (Anders et al., 2007; Tremblay et al., 2015; Zlatkin et al., 2014, 2017 and references therein; Fig. 2a): (1) pre-Alpine continental basement, (2) Permo-Triassic metaclastics and Mesozoic marbles, sealed by (3) a Sub-Pelagonian section of Jurassic ophiolites and Upper Cretaceous pelagic and neritic carbonates overlain by the Eocene flysch (Fig. 2a). On the opposite or eastern side (Fig. 1c) is the Vardar / Axios Zone of Inner Hellenides. This ophiolite-bearing zone or eastern side of the Pelagonian block is aligned with the western margin of the Serbo-Macedonian Unit. The Neoproterozoic - Paleozoic framework of Pelagonide basement (proto-Basement) comprises gneiss, granitoides and orthogneiss, schists (metasediments) with early Mesozoic clastics (e.g. Zlatkin et al., 2014, 2017; Fig. 2a). The northern gneiss-dominating basement branch of the Pelagonides (North Macedonia; see Spahić et al., 2019a and references therein) and those of Greece are of mixed peri-Amazonian inheritance (i.e. Zlatkin et al., 2017). The Variscan-Cimmerian markers likewise Permo-Triassic metaclastics document a Paleotethyan involvement (Mountrakis, 1986; Vavvasis et al., 2000; Scherreiks et al., 2014; Zlatkin et al., 2014, 2017).

The Drina-Ivanjica block crops out exposing two considerably large segments: the northwestern flank or the Drina block and its southern 


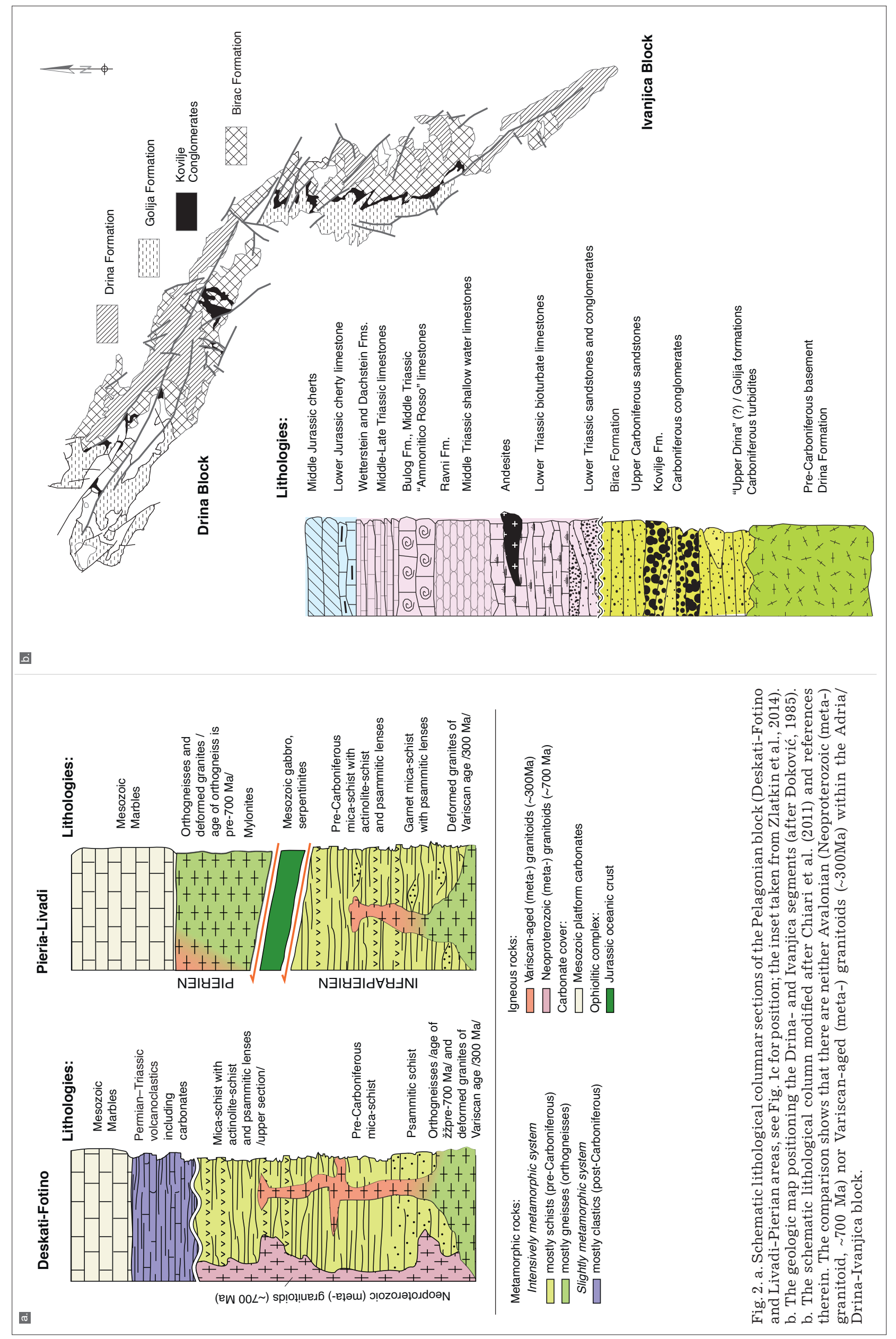


limb referred to as the Ivanjica block (Figs. 1 and 2b). Stratigraphically, the oldest Neoproterozoic-lower Paleozoic segment is the Drina Formation (Đoković, 1985; Filipović \& Sikošek, 1999). The complex depositional environment of the Drina Formation belongs to the ancient north Gondwanan margin (Spahić et al., 2018). The early/late Carboniferous and late Triassic successions (i.e. Dimitrijević, 1997; Trivić et al., 2010; Chiari et al., 2011) seal this basement unit. The Drina Formation includes scarce paragneisses, micaschists, amphibolites and minor marble lenses of Neoproterozoic - Lower Paleozoic age. The "Upper Drina Formation" (metasandstones and metapelites and metacarbonates with a Visean/Namurian conodont fauna) conformably overlies the "Lower Drina Formation". There is still an open issue of unproven Silurian that is remarkably well developed in eastern Serbia (e.g., Krstić et al., 2005; Spahić et al., 2019b). The Golija Formation, represented by metasandstones, metasiltstone, succeeds the latter formation. The Golija Formation is conformably top-sealed by the Kovilje Formation carrying early/late Carboniferous metaconglomerates and metasandstones. The Kovilje Formation grades into the late Carboniferous Birač Formation consisting of (Bashkirian/Moscovian) metasandstones, metalimestones and metapelites. The Mesozoic sequence is well studied and is represented by the Triassic Kladnica and "Seissian" Formations reaching Middle Jurassic with cherts as the sealing member (Fig. 2b). Neither the magmatic occurrence of the Avalonian stage (ca. 700 $\mathrm{Ma}$ ) nor the typifying Permian-Triassic imprints of Eocimmerian relevance are recorded within the Drina-Ivanjica block. To make things even more perplexing, the Variscan involvement of the Adria remains poorly constrained (Đoković, 1985; Xypolias et al., 2005; Okay et al., 2006; see Spahić et al., 2019c, for a discussion). On the other hand, the principal differences between the latter two polycrystalline units, the Drina-Ivanjica block and the Pelagonides (Fig. 1c) were suggested almost a century ago (e.g. Cvijić, 1924).

\section{Early development of the landlocked northwestern PeriNeotethyan oceans}

Prominent researchers of former Yugoslavia (Dimitrijević, 1992, also in Protić, 1995 p. 16; Fig. 1b; Dimitrijević, 1997; 2001; Dimitrijević et al., 2003; Karamata, 2006; Fig. 2a) subdivide the Vardar Zone (here referred to as the Vardar Zone s.s.) into the Western Vardar Zone, Kopaonik Block, and East Vardar Zone (note that the Inner Dinaric Ophiolite Belt is a separate entity; Fig. 3a). The tectonic concepts of the investigated area of eastern Bosnia and western Serbia, and the proposed first-order units by the aforementioned researchers are almost identical. Dimitrijević (e.g., Dimitrijević, 1997) and Karamata (e.g. Karamata \& Krstić, 1996; Karamata, 2006) share the same opinion about the position of the main geotectonic units (Fig. 1b). However, with regards to the adjoining Jadar Block (sensu Filipović et al., 2003; Kolar-Jurkovšek et al., 2019; Fig. 1b; Fig. 2), this rather isolated entity can be considered either as a (1) footwall entity overridden by the West Vardar ophiolite obduction (Schmid et al., 2008, 2020; Fig. 3b), (2) segment of the Vardar Zone (Dimitrijević, 1997; Fig. 1b) or a Paleozoic entity drifted into the Vardar Zone during the Late Cretaceous (Karamata et al., 1994). Recently, a Paleotethyan involvement for the Jadar Block is suggested (Spahić \& Gaudenyi, 2020a). The nearby Tisza Unit is the plate/ block is separated by the Vardar Zone s.s. from the Jadar (Fig. 1b). The overlying sediments belonging the southern Pannonian Basin (Csontos \& Vörös, 2004) hid the contact between the microplates. The southern edge of this underlying Tisza crystalline basement is interfacing both, Inner Dinarides and Vardar Zone. Such complexity between a varieties of the Mesozoic sequences is controlled by the structurally underlying basement entities and their remobilization.

Fig. 3. a. Position of the eastern boundary of the Dinarides, i.e. Drina-Ivanjica block at more external positions towards the Vardar Zone (modified after Dimitrijević \& Dimitrijević, 1973; Dimitrijević, 2001). The Inner Dinaric Ophiolite belt is a separate Jurassic ophiolite-bearing entity which spreading initially displaced Drina-Ivanjica into a separate ribbon shape crustal fragment. The arrows indicate the ophiolite movements during the Jurassic Neotethyan closure. The blue arrows indicate a 'single ocean', green and light brown the ophiolite movements of the two discrete oceans.

b. Regional schematic cross section across the Dinarides and the Vardar Zone, up to the Serbo-Macedonian Unit (redrawn from Csontos et al., 2004; also in Csontos \& Vörös, 2004). The interpreted cross section favors 'single ocean model', explaining far-travelled ophiolite obduction on top and beyond the Drina-Ivanjica block. 


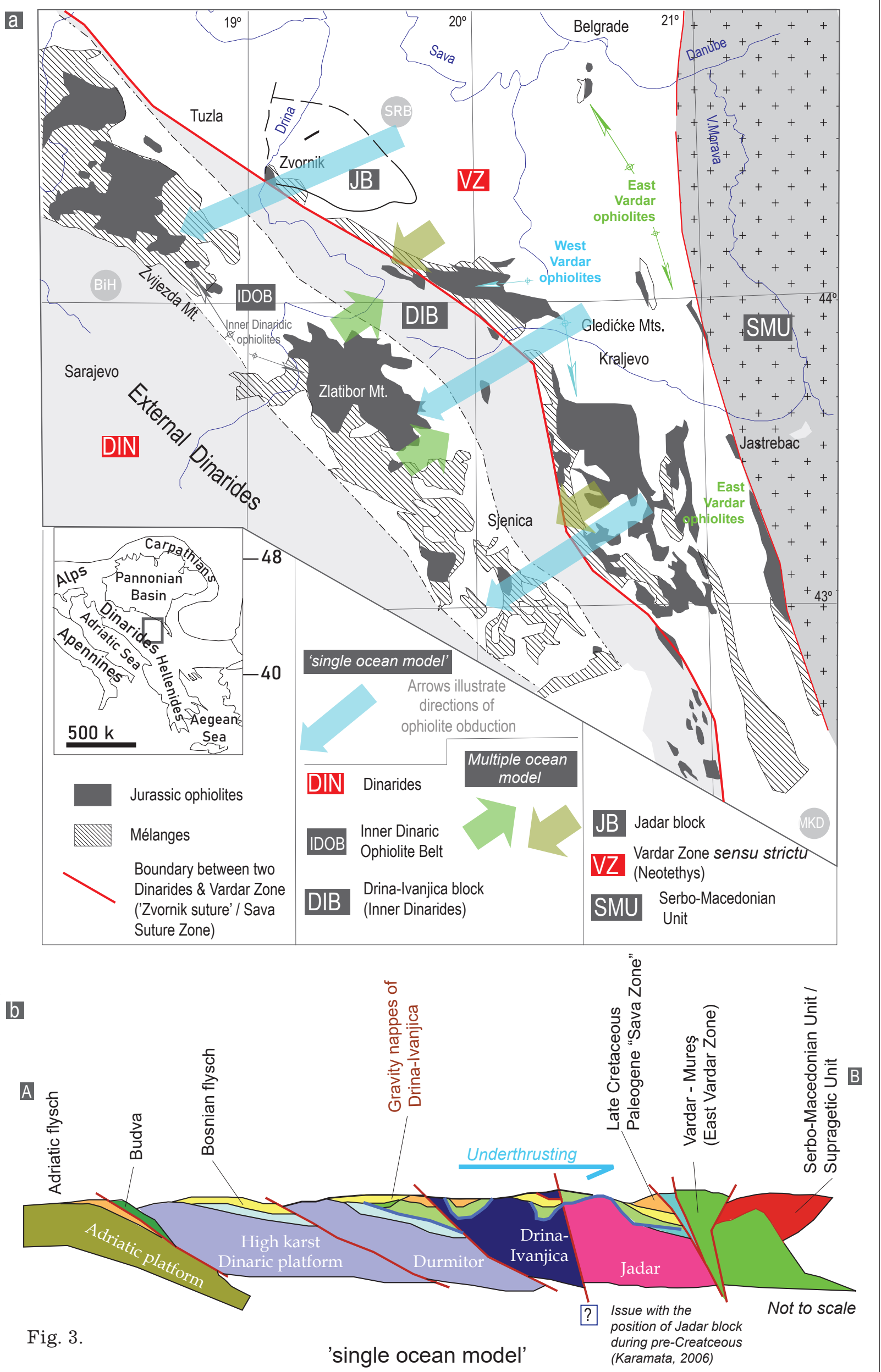




\section{The Paleozoic input for the early Vardar developments}

The differences between the NE Adria microplate and the Pelagonian block as input for Variscan Eocimmerian - Neotethyan inferences

An Avalonian inheritance of the Pelagonian basement has recently been documented (Zlatkin et al., 2014, 2017). Such Neoproterozoic paleocontinental inferences (ca. $600 \mathrm{Ma}$ old orthogneisses and overstepping late Ediacaran to earliest Cambrian metasedimentary rocks) indicated Avalonian - Amazonian inheritance i.e a position that is associated with a West African Gondwana proximity, not North African (see Fig. 4 of Spahić et al., 2018 and references therein; Zlatkin et al., 2017). The documented Amazonian paleocontinental inheritance stresses a considerable difference in the early Paleozoic paleoposition with respect to the so-called Cadomian-type 'Paleo-Adria' (detrital zircon data by Siegesmund et al., 2018). The 'Paleo-Adria' was accommodated in front of the early Paleozoic North Africa (Franke et al., 2017).

The 'Paleo-Adria' represents a crustal fragment of the early Paleozoic North African promontory being a predecessor of the Apulia/Adria microplate (Franke et al., 2017). This considerably large microplate was disconnected from the North African margin during the Silurian. Some though earlier studies suggest the Permian or Triassic detaching (e.g. Bernoulli, 2001 and references therein; van Hinsbergen et al., 2020). Both concepts nevertheless illustrate the Variscan involvement of the Adria (Pamić \& Jurković, 2002) that in turn has not been fully validated across the Dinarides (Okay et al., 2006; Spahić et al., $2020 \mathrm{c})$. The main problem of the eventual Variscan interference revolves around the age of the metamorphic overprint has often been dated as of the dominant Alpine relevance i.e. of Jurassic age (e.g., Milovanović, 1984; Porkoláb et al., 2018;). Scarce structural evidence of the tentative Variscan involvement of these Neotethyan basement units is identified earlier (sensu Đoković, 1985; Borojević-Šoštarić et al., 2012). According to the deformations (i.e. Đoković, 1985), it appears that the Drina-Ivanjica block amalgamated with the southwestern Euroasia during the protracted Variscan shortening (Pamić \& Jurković, 2002). The late Paleozoic Apulia/Adria occupied westernmost corner of Pangea (see discussion Maffione \& van Hinsbergen, 2018; Avigad et al., 2016 and references therein; Spahić \& Gaudenyi, 2020a; Fig. 4). Rare rock cooling fission track measurements of the crystalline basement rocks associated with the Apulia/Adria microplate
(External Dinarides, Croatia) occasionally exhibit the Variscan exhumation age (or ${ }^{40} \mathrm{Ar} /{ }^{39} \mathrm{Ar}$ plateau ages at $342.9 \pm 3.3 \mathrm{Ma}$ and $332.8 \pm 3.1 \mathrm{Ma}$ in the Sana-Una Unit, Petrova- and Trgovska Gora; Borojević-Šoštarić et al., 2012 and references therein). More frequent is the Alpine exhumation framework having the cooling ages in the range from 159-92 $\mathrm{Ma}$ and 50-37 Ma (Mid-Bosnian Schist; Borojević-Šoštarić et al., 2012 and references therein). The issue of the Variscan involvement is rather important as it validates i.e., rules out an eventual Eocimmerian involvement of this microplate (see Stampli et al., 2001, for a discussion). Unlike the Adria microplate, the Pelagonian block has a documented evidence of both Variscan and post-Variscan Paleotethyan involvement (Vavvasis et al., 2000; Zulauf et al., 2015). Earlier studies suggested that the Pelagonian block is a fragment of Cimmerian ribbon continent (Mountrakis, 1986).

Reconsidering the Jurassic-early Cretaceous position of the Drina-Ivanjica- and Pelagonian blocks

The western Pelagonian basement is overridden by the stacked ophiolite-bearing slices of Tethyan relevance referred to as the Mirdita-Pindos-Vourinos (Tremblay et al., 2015 and references therein). Eastern side is characterized by the Early Permian to Early/Middle Triassic rift stage followed by the Middle Triassic Maliac oceanization (De Bono et al., 2001). The majority of the reconstructions illustrate the Drina-Ivanjica block plus Pelagonian basement as a continental segment onto which the Late Jurassic - early Cretaceous Neotethyan or Western Vardar ophiolites were obducted (e.g., Hrvatović \& Pamić, 2005; Schmid et al., 2008). However, several new inferences imply a different unaligned position of the two basement units.

The Pelagonian block had two different positions throughout the Paleozoic that unambiguously affected its Jurassic location. The paleocontinental inheritance data indicate the two different locations throughout the late Paleozoic: (i). Pelagonian block may represent a segment of the Euroasian margin directed towards the Sakaraya segment positioned to the east of Paleotethyan pivot point (e.g., Vavvasis et al., 2000; Fig. 4). Meaning that the Pelagonian block may represent a crustal fragment or as a crustal fragment separately involved in the Variscan amalgamation of southern Variscan belt (see Zulauf et al., 2015, for a discussion; Spahić et al., 2019b). This marginal crustal fragment underwent 
immediate early Permian exhumation (ages are 295-280 Ma; Vavassis et al., 2000), which is not the case for the Adria/Apulia. Consequently, both positions proposed for the Pelagonian fragment have a different early Alpine i.e. pre-rift locations relative to the Apulia/Adria. In other words, the Pelagonian block cannot to be aligned with the Drina-Ivanjica block as the northeastern most Adria tip which was more to the west. This paleogeographic situation lasted during the Permian-Triassic (Fig. 4), probably continuing during the Jurassic (Stampfli \& Kozur, 2006). The early Alpine extension and interference of the terminal Paleotethyan rollback stage (Vavvasis et al., 2000; Stampfli \& Borel, 2002: see reconstructions of Moix et al., 2008) induced the embayment of the intervening Maliac Ocean (between Pelagonian block and Serbo-Macedonian Unit; De Bono et al., 2001; Ferrière et al., 2012, 2016; Spahić et al., 2020). The opening of the Maliac produced by the Permian extension (Fig. 4), triggered a rifting off the Pelagonide block, moving it slightly away from the South Euroasian margin or away from the southern Serbo-Macedonian Unit, and its hinterland (also referred to as the "Transdanubian", Moix et al., 2008). Thus, the Pelagonian microplate was sandwiched between the Pindos (to the west) and Maliac Ocean (to the east)

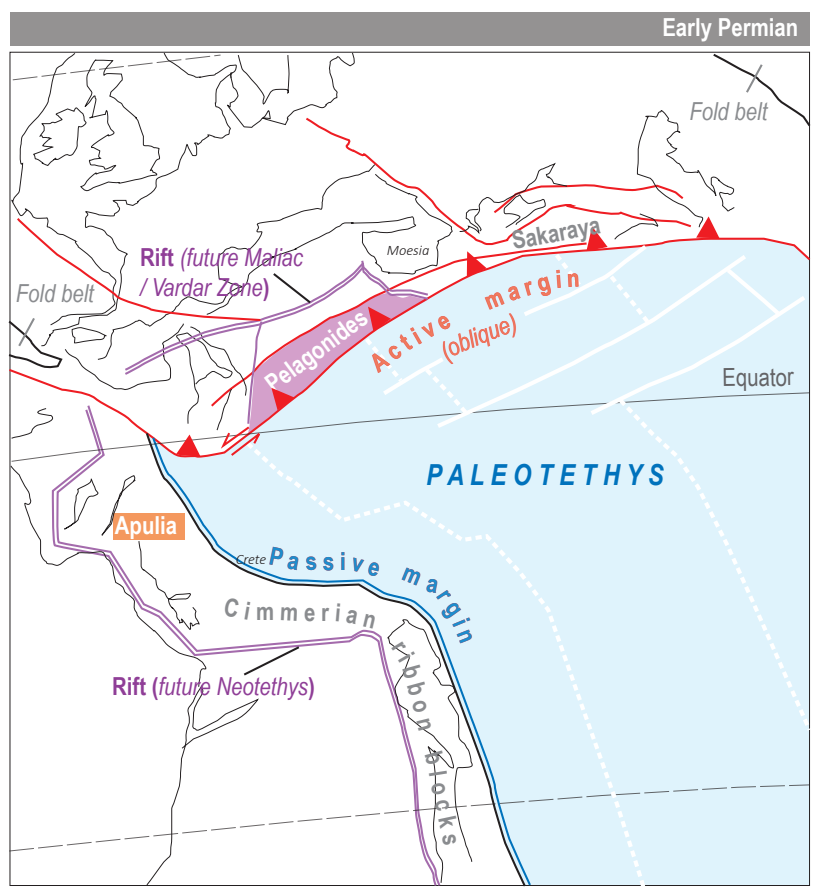

Fig. 4. The position of the Pelagonian block relative to Apulia microplate during Early Permian (inset from Vavvasis et al., 2000 , slightly modified). The figure pinpoints the position of the Pelagonian block (to the east, adjoining the Sakaraya block), relative to the Apulia, which was more towards the westernmost pivot point of Paleotethys. during Late Triassic (see reconstruction of Vavvasis et al., 2000; Stampfli \& Kozur, 2006; Moix et al., 2008; Zulauf et al., 2015). The modern-day stacked architecture of the pre-Neogene nappes of the External Hellenides is response of the northward Cenozoic subduction (Pindos Ocean) and collision between the Apulia and the Pelagonian microcontinent (Mountrakis 1986; Xypolias et al., 2005).

Considering the separate position of the Drina-Ivanjica block (and entire Apulia/Adria) from the Pelagonian microplate, such a relationship suggests that the early Pindos Ocean could have been in connection with the "Dinaric Tethys". This paleocean was to the west of the Pelagonides and to the southeast of the Drina-Ivanjica block (similar as in Channel \& Kozur, 1997; Fig. 5). To the north, the "Dinaric Tethys" as an Upper Triassic - Upper Jurassic segment of a separate Neotethyan mini-ocean was already closed by the early Cretaceous (Pamić, 1998; Faul et al., 2014; Fig. 5). The "Pindos - Mirdita - Dinaric Tethys" oceanic entity (not seaway as there is a documented evidence of separate Jurassic oceanic crust) had no direct link with the more internal Triassic Maliac Ocean (as proposed by Faul et al., 2014). On the other hand, being in the intervening position, the issue of the inheritance of the Adria-derived Kopaonik system (Zelić et al., 2005, 2010; Schefer et al., 2010) remains open for another set of future inferences.

In the early Mesozoic paleogeographic context, during a limited Jurassic interval, several oceans (oceanic lithosphere developed) were identified in the area of the Western Balkan countries (Fig. 5; also, in Dimitrijević, 2001; Karamata, 2006; Stampfli \& Kozur, 2006; Spahić \& Gaudenyi, 2020c). The developments of the NW Neotethys or Vardar Ocean corresponds to the crustal extension of the Adria microplate and the formation of, at least, two marginal micro-oceans: the "Dinaric Tethys" seems to be a kind of "Red Sea-type" narrow landlocked ocean (Robertson \& Karamata, 1994). This rather confined oceanic tract was in the proximity of the advancing Jurassic Vardar Ocean divided by the "Drina - Pelagonide continental splinter", yet in connection with the latter (to the west of Jadar block; Fig. 5). The two oceanic entities can be easily traced by the central-positioned Jurassic continental splinter Drina-Ivanjica continental block (Figs. 1b and 5). The Pelagonian microplate was presumably a segment of the early Alpine south Euroasian margin, a crystalline block which inherited its position after the Variscan amalgamation, 


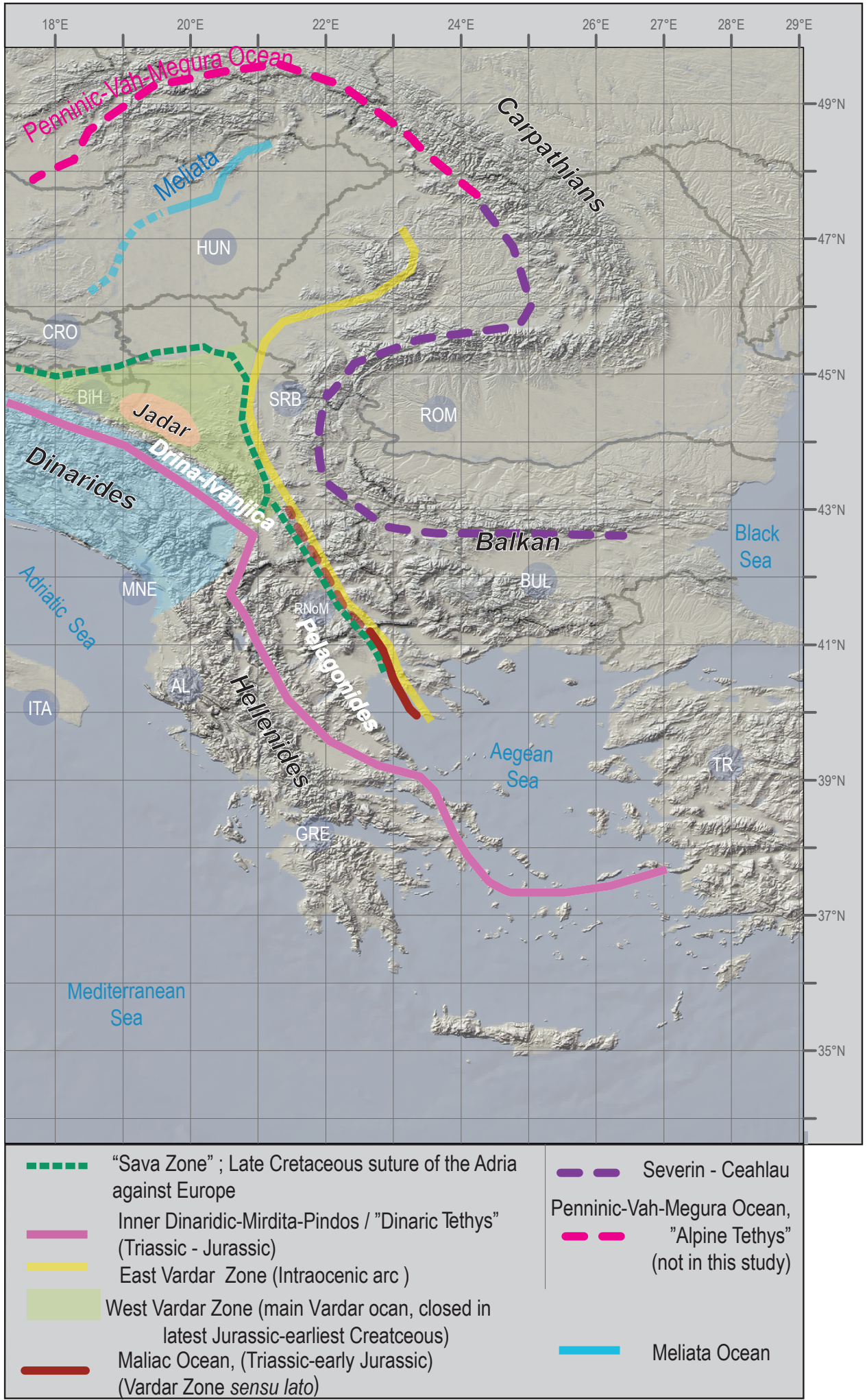

Fig. 5. The remnants of Mesozoic oceanic troughs (ophiolite belts, suture zones) and microcontinents in the wider CarpathianBalkan, Dinaride-Hellenide areas (some suture traces taken from Csontos and Vörös, 2004, modified and updated). The "Sava Zone" (sensu Pamić, 2002) represents a version of the "Late Cretaceous suture" (beyond the scope of this paper). The Drina-Ivanjica block and Pelagonide block are engulfed by several suturing-related troughs: "Dinaric Tethys" to the west, West Vardar Zone to the east, including the "Sava Zone" and the precursory Maliac Ocean.

spatially overridden only after the final emplacement of the Vardar ophiolite during Valanginian time (initiated at latest Bathonian to Early Callovian; Scherreiks et al., 2014), i.e. Early Jurassic consummation of the precursory Maliac Ocean.

During the terminal late Jurassic stage and the closure of the main Neotethys, the Vardar oceanic lithosphere underthrusted the intra-ocean- ic system (East Vardar Zone) positioned in front of the Serbo-Macedonian Unit (e.g., Boev et al., 2018; Spahić \& Gaudenyi, 2019; Figs. 3a and 4). Across the opposite side of the Jurassic 'Zvornik suture', in line with the closure of the Neotethys or Vardar Ocean, the West Vardar were ophiolites obducted onto the Adria passive margin (Spahić and Gaudenyi, 2020c). The East Vardar Zone in 
North Macedonia was at the back of the Pelagonian basement block, whereas the late Paleocene - Lower Miocene shortening (underthrusting of Apulia beneath Pelagonian block) closed the Pindos Ocean (Xypolias et al., 2008 and references therein). Consequently, there were at least two discrete Triassic-early Jurassic marginal oceanic entities accommodated on both sides of the Pelagonian microplate (Pindos- and Maliac oceans; $c f$. Ferrière et al., 2012). With regards to the postdating Late Cretaceous - Paleogene "Sava(-Vardar) Zone" (sensu Pamić, 2002; Schmid et al., 2008) as the principal "oceanic" or Neotethyan suture (Fig. 5), there is no solid evidence of the existence of the post-Jurassic oceanic crust (see Cvetković et al., 2016, for a discussion; Spahić \& Gaudenyi, 2021).

\section{Conclusions}

The study emphasizes the Triassic - Jurassic paleogeography of the seemingly interlinked regional microplates: Adria/Apulia with the Drina-Ivanjica block and Inner Dinaric Ophiolite belt, from Pelagonides and Western Vardar oceanic lithosphere. The results show the presence of the two probably subduction-driven distinct Jurassic Tethyan oceans abutting Drina-Ivanjica and Pelagonian block ("Drina-Pelagonide continental splinter"): The Inner Dinaric-(Mirdita-Pindos) Ocean / "Dinaric Tethys" (identified by the Inner Dinaric Ophiolite Belt) and the Vardar Ocean (identified by the West Vardar Zone of Karamata, 2006). The "Dinaric Tethys" / Inner Dinaric-(Mirdita-Pindos) ocean was situated to the southwest of the "Drina-Pelagonian splinter" or Drina-Ivanjica block and to the west of the Pelagonides, whereas the main Neotethys was towards the east.

\section{Acknowledgement}

This research did not receive any specific grant from funding agencies in the public, commercial or not-for-profit sectors. We are grateful anonymous reviewers for constructive and helpful comments on the manuscript. We thank Bernarda Bole for guidance throughout the manuscript review process.

\section{References}

Anders, B., Reischmann T. \& Kostopoulos, T. 2007: Zircon geochronology of basement rocks from the Pelagonian Zone, Greece: constraints on the pre-Alpine evolution of the westernmost Internal Hellenides. International Journal of Earth Sciences, 96: 639-661.
Avigad, D., Abbo, A. \& Gerdes, A. 2016: Origin of the Eastern Mediterranean: Neotethys rifting along a cryptic Cadomian suture with Afro-Arabia. Geological Society of America Bulletin, 128/7-8: 1286-1296.

Bernoulli, D. \& Jenkyns, H.C. 1974: Alpine Mediterranean and central Atlantic Mesozoic facies in relation to the early evolution of the Tethys. SocietyofEconomicPaleontologistsand Mineralogists - Special Publication 18: 129-160.

Bernoulli, D. \& Laubscher, H. 1972: The palinspastic problem of the Hellenides. Eclogae geologicae Helvetiae, 65: 107-118.

Boev, B., Cvetković, V., Prelević, D., Šarić, K. \& Boev, I. 2018: East Vardar ophiolites revisited: A brief synthesis of geology and geochemical data. Contributions, Section of Natural, Mathematical and Biotechnical Sciences. Macedonian Academy of Sciences and Arts, 39/1: 51-68

Bortolotti, V., Chairi, M., Marroni, M., Pandolfi, L., Principi, G. \& Saccani, E. 2013: Geodynamic evolution of ophiolites from Albania and Greece (Dinaric-Hellenic belt): one, two, or more oceanic basins? International Journal of Earth Sciences, 102: 783-811.

Borojević Šostarić, S., Neubauer, F., Handler, R. \& Palinkaš, L. A. 2012: Tectonothermal history of the basement rocks within the NW Dinarides: New ${ }^{40} \mathrm{Ar} /{ }^{39} \mathrm{Ar}$ ages and synthesis. Geologica Carpathica, 63/6: 441-452. https:// doi.org/10.2478/v10096-012-0034-2

Channel, J.E.T. \& Kozur, H.W. 1997: How many oceans? Meliata, Vardar, and Pindos oceans in Mesozoic Alpine paleogeography. Geology, 25/2: 183-186.

Chiari, M., Djerić, N., Garfagnoli, F., Hrvatović, H., Krstić, M., Levi, N., Malasoma, A., Marroni, M., Menna, F., Nirta, G., Pandolfi, L., Principi, G., Saccani, E., Stojadinović, U. \& Trivić, B. 2011: The Geology of the ZlatiborMaljen Area (Western Serbia): A Geotraverse across the Ophiolites of the Dinaric-Hellenic Collisional Belt. Ofioliti, 36/2: 139-166.

Csontos, L., Gerzina, N., Hrvatović, H., Schmid, S.M. \& Tomljenović, B. 2004: Structural evolution of the Internal Dinarides: a preliminary study based on selected regions. 5th International Symposium on Eastern Mediterranean Geology, Thessaloniki, Greece, 14-20. April 2004, T11-7.

Csontos, L. \& Vörös, A. 2004: Mesozoic plate tectonic reconstruction of the Carpathian region. Palaeogeography, Palaeoclimatology, Palaeoecology, 210: 1-56. 
Cvetković, V., Prelević, D. \& Schmid, S. 2016: Geology of South-Eastern Europe. In: Papic, P. (eds.): Mineral and Thermal Waters of Southeastern Europe. Environmental Earth Sciences book series. Springer International Publishing, 1-29.

Cvijić, J. 1924: Geomorfologija - Mophologie Terrestres. Državna štamparija SHS. Belgrade. 1588 p. (in Serbian)

De Bono, A., Martini, R., Zaninetti, L., Hirsch, F., Stampfli, G.M. \& Vavassis, I. 2001: PermoTriassic stratigraphy of the Pelagonian zone in central Evia island (Greece). Eclogae Geologicae Helvetiae, 94: 289-311.

Dilek, Y. \& Furnes, H. 2005: Tethyan ophiolites and Tethyan seaways. Journal of the Geological Society, 176: 899-912.

Dilek, Y., Shallo, M. \& Furnes, H. 2005: Rift-drift, seafloor spreading, and subduction tectonics of Albanian ophiolites. International Geological Review, 47: 147-176.

Dilek, Y., Shallo, M. \& Furnes, H. 2007: Suprasubduction zone ophiolite formation along the periphery of Mesozoic Gondwana. Gondwana Research, 11: 453-475.

Dimitrijević, M. 1992: Geološka karta Srbije 1: 2,000,000 (Geološki atlas 1) = Geological Map of Serbia, 1: 200,000 (Geological Atlas 1). Faculty of Mining and Geology - University of Belgrade and Geozavod Gemini, Belgrade. (in Serbian)

Dimitrijević, M.D. 1997: Geology of Yugoslavia. Geoinstitute, Belgrade: 182 p.

Dimitrijević, M. 1999: Geotectonic map in scale 1: 2,000,000. Ministry for Mining and Energetics of Serbia and Geomagnetic Institute. Belgrade.

Dimitrijević, M.D. 2001: Dinarides and the Vardar Zone: a short review of the geology. Acta Vulcanologica, 13/1-2: 1-8.

Dimitrijević, M.D. \& Dimitrijević, M.N. 1973: Olistostrome Mélange in the Yugoslavian Dinarides and Late Mesozoic Plate Tectonics. The Journal of Geology, 81/3: 328-340. https:// www.jstor.org/stable/30084828

Dimitrijević, M.D. \& Dimitrijević, M.N. 1975: Ofiolitski melanž Dinarida i Vardarske Zone: Geneza i geotektonsko značenje = Ophiolite mélange of the Dinarides and the Vardar Zone: Genesis and its geotectonic importance. II godišnji znanstveni skup, Znanstveni savjet za naftu JAZU, Sekcija za primjenu geologije, geofizike i geokemije, ser. A, 5: Zagreb. 39-46. (in Serbo-Croatian)
Dimitrijević, M.N., Dimitrijević, M.D., Karamata, S., Sudar, M., Gerzina, N., Kovács, S., Dosztály, L., Gulászi, Z., Less, G. \& Pelikán, P. 2003: Olistostome/mélanges - an overview of the problems and preliminary comparison of such formations in Yugoslavia and NE Hungary. Slovak Geological Magazine, 9/1: $3-21$.

Đoković, I. 1985: Primena strukturne analize na rešavanje građe paleozojskih tvorevina Drinsko-Ivanjičke oblasti = Application of structural analsiys in solving the Paleoezoic formations of Dirina-Ivanjica area - In Serbian. Geološki anali Balkanskoga poluostrva, 49: 11-160. (in Serbian, English summary).

Faul, U.H., Garapić, G. \& Lugović, B. 2014: Subcontinental rift initiation and oceancontinent transitional setting of the Dinarides and Vardar zone: Evidence from the Krivaja - Konjuh Massif, Bosnia and Herzegovina. Lithos, 202-203: 283-299.

Ferrière, J., Baumgartner, P.O. \& Chanier, F. 2016 : The Maliac Ocean: the origin of the Tethyan Hellenic ophiolites. International Journal of Earth Sciences, 105/7: 1941-1963.

Ferrière, J., Chanier, F. \& Ditbanjong, F. 2012: The Hellenic ophiolites: eastward or westward obduction of the Maliac Ocean, a discussion. International Journal of Earth Sciences, 101/6: 1559-1580.

Filipović, I. \& Sikošek, B. 1999: Pre-Variscan and Variscan successions of the Drina anticlinorium and the Drina-Ivanjica Paleozoic. Bulletin, Tome 119 Serbain Academy of Sciences and Arts, Classe Sciences mathematiques et naturalles, Sciences naturelles, 39: 61-71.

Filipović, I., Jovanović, D., Sudar, M., Pelikán, P., Kovács, S., Less, G. \& Hips, K. 2003: Comparison of Variscan-early Alpine evolution of the Jadar Block (NW Serbia) and "Bükkium" (NE Hungary) terranes; some paleogeographic implications. Slovak Geological Magazine, 9/1: 23-40.

Franke, W., Cocks, L.R.M. \& Torsvik, T.H. 2017. The Palaeozoic Variscan oceans revisited. Gondwana Research, 48: 257-284.

Gaggero, L., Marroni, M., Pandolfi, L. \& Buzzi, L. 2009: Modeling the oceanic lithosphere obduction: Constraints from the metamorphic sole of Mirdita ophiolites (northern Albania). Ofioliti, 34/1: 17-42.

Gerzina, N. 2010: Strukturne karakteristike i tektogeneza Zvorničkog šava = Structural 
Characteristic and Tectogenesis of Zvornik Suture zone. PhD-thesis, Belgrade University, Faculty of Mining and Geology (manuscript), Beograd: $142 \mathrm{p}$.

Goričan, S., Karamata, S., Batočanin-Srećković, D. 1999: Upper Triassic (Carnian-Norian) radiolarians in cherts of Sjenica (SW Serbia) and the time span of the oceanic realm ancestor of the Dinaridic Ophiolite Belt. Bulletin de l'Académie Serbe des Sciences et des Arts 119 - Classe Sciences Mathématiques et Naturelles, 39: 141-149.

Handy, M.R., Ustaszewski, K. \& Kissling, E. 2015: Reconstructing the Alps-CarpathiansDinarides as a key to understanding switches in subduction polarity, slab gaps and surface motion. Int J Earth Sci (Geol Rundsch), 104: $1-26$.

van Hinsbergen, D.J.J., Torsvik, T.H., Schmid, S.M., Mațenco, L.C., Maffione, M., Reinoud L.M., Gürer, D. \& Spakman, W. 2020: Orogenic architecture of the Mediterranean region and kinematic reconstruction of its tectonic evolution since the Triassic. Gondwana Research, 81: 79-229. https://doi.org/10.1016/j. gr.2019.07.009

Hrvatović, H. \& Pamić, J. 2005: Principal thrust-nappe structures of the Dinarides. Acta Geologica Hungarica, 48/2: 133-151. https:// doi.org/10.1556/ageol.48.2005.2.4

Jolivet, L., Faccena, C., Agard, P., de Lamotte, D.F., Menant, A. Sternai, P. \& Guillocheau, F. 2016: Neo-Tethys geodynamics and mantle convection: from extension to compression in Africa and a conceptual model for obduction. Canadian Journal of Earth Sciences, 53/11: 1190-1204. https://doi.org/10.1139/ cjes-2015-0118

Karamata, S. 2006: The geological development of the Balkan Peninsula related to the approach, collision and compression of Gondwanan and Eurasian units. In: Robertson, A.H.F. \& Mountrakis, D. (eds.): Tectonic Development of the Eastern Mediterranean Region. Geological Society of London, Special Publication, 260: 155-178.

Karamata, S. \& Krstić, B. 1996: Terranes of Serbia and neighbouring areas. In: KneževićĐorđević, V. \& Krstić, B. (eds.): “Terranes of Serbia" - The Formation of the geologic framework of Serbia and Adjacent regions. Department of Petrology; Faculty of Mining and Geology - University of Belgrade, Belgrade: 25-40.
Karamata, S., Knežević, V., Memović, E. \& Popević, A. 1994: The evolution of the northern of the Vardar Zone in Mesozoic. Bulletin of the Geological Society of Greece, 32: 479-486.

Kearey, P., Klepeis, K.A. \& Vine, F.J. 2009: Global Tectonics. Wiley-Blackwell: $496 \mathrm{p}$.

Kolar-Jurkovšek, T., Hrvatović, H., Aljinović, D., Nestell, G.P., Jurkovšek, B. \& Skopljak, F. 2019: Konodonti profila Teočak: granica perm-trijas (Conodonts of the Teočak section: Permian-Triassic boundary - in Bosnian). In: Zbornik radova, 6. knjiga sažetaka. II Kongres geologa Bosne i Hercegovine 2-4.10.2019. Udruženje / Udruga geologa Bosne I Hercegovine, Laktaši: 2-4.

Kroner, U. \& Romer, R.L. 2013: Two plates many subduction zones: The Variscan orogeny reconsidered. Gondwana Research, 24: 298-329

Krstić, N., Maslarević, L.J. \& Sudar, M. 2005: On the Graptolite Schists Formation (SilurianLower Devonian) in the Carpatho-Balkanides of eastern Serbia. Geološki anali Balkanskoga poluostrva, 66: 1-8.

Maffione, M. \& van Hinsbergen, D.J.J. 2018: Reconstructing plate boundaries in the Jurassic Neo-Tethys from the East and West Vardar Ophiolites (Greece and Serbia). Tectonics, 37/3: 858-887.

Milovanović, D. 1984: Petrology of low-metamorphic rocks from the central part of the Drina-Ivanjica Paleozoic. Glasnik Prirodnjačkog Muzeja ser. A, 39: 13-139 (in Serbian with English summary).

Mountrakis, D. 1986: The Pelagonian zone in Greece, a polyphase deformed fragment of the Cimmerian continent and its role in the geotectonic evolution of the Eastern Mediterranean. Journal of Geology, 94/3: 335-347. https://doi.org/10.1086/629033

Nance, D. 1981: Tectonic history of a tectonic segment of the Pelagonian zone, north-eastern Greece. Canadian Journal of Earth Sciences, 18: 1111-1126.

Neubauer, F., Yoingjiang, L., Shuyun, C.\& Yuan, S. 2019: What is the Austroalpine mega-unit and what are the potential relations to Paleotethyan ocean remnant of southeastern Europe? Proceedings of the Geologica Carpathica 70 Conference. Earth Science Institute of the Slovak Academy of Sciences. Bratislava. 16-20.

Pamić, J. 2002: The Sava-Vardar Zone of the Dinarides and Hellenides versus the Vardar Ocean. Eclogae geologicae Helvetiae, 95: 99-113. 
Pamić, J. \& Jurković, I. 2002: Paleozoic tectonostratigraphic units of the northwest and central Dinarides and the adjoining South Tisia. International Journal of Earth Sciences, 91/3: 538-554. https://doi.org/10.1007/ s00531-001-0229-8

Pamić, J., Gušić, I. \& Jelaska, V. 1998: Geodynamic evolution of the Central Dinarides. Tectonophysics, 297: 251-268.

Picha, F.J. 2002: Late orogenic strike-slip faulting and escape tectonics in frontal DinaridesHellenides, Croatia, Yugoslavia, Albania, and Greece. American Association of Petroleum Geologists Bulletin, 86/9: 1659-1671.

Porkoláb, K., Kövér, S., Benkó, Z., Héja, G.H., Fialowski, M., Soós, B., Gerzina Spajić, N., Đerić, N. \& Fodor, L. 2018: Structural and geochonological constraints from the DrinaIvanjica thrust sheet (Western Serbia): Implications for the Cretaceous - Paleogene tectonics of the Internal Dinarides. Swiss Journal of Geosciences, 112: 1-18. https://doi. org/10.1007/s00015-018-0327-2

Protić, D. 1995: Mineralne i termalne vode Srbije = Mineral and Thermal waters of Serbia. Geoinstitut: 270 p. (in Serbian).

Robertson, A.H.F. 2012: Late Palaeozoic-Cenozoic tectonic development of Greece and Albania in the context of alternative reconstructions of Tethys in the Eastern Mediterranean region. International Geology Review, 54/4: 373-454. https://doi.org/10.1080/00206814.2010.543791

Robertson, A. \& Karamata, S. 1994. The role of subduction-accretion processes in the tectonic evolution of the Mesozoic Tethys in Serbia. Tectonophysics, 234: 73-94. https:// doi.org/10.1016/0040-1951(94)90205-4

Robertson, A., Karamata, S. \& Šarić, K. 2009: Overview of ophiolites and related units in the Late Palaeozoic-Early Cenozoic magmatic and tectonic development of Tethys in the northern part of the Balkan region. Lithos, 108: 1-36. https://doi.org/10.1016/j. lithos.2008.09.007

Saccani, E., Photiades, A., Sontato, A. \& Zeda, O. 2008: New evidence for supra-subduction zone ophiolites in the Vardar Zone of norther Greece: implications for the tectono-magmatic evolution. of the Vardar Oceanic basin. Ofioliti, 33: 65-85.

Saccani, E., Beccaluva, L. Photiades, A. \& Zeda, O. 2011: Petrogenesis and tectonomagmatic significance of basalts and mantle peridotites from the Albanian-Greek ophiolites and sub-ophiolite mélanges. New constraints for the Triassic-Jurassic evolution of the TriassicJurassic evolution of the Neo-Tethys in Dinaride sector. Lithos, 124/3-4: 227-242. https://doi.org/10.1016/j.lithos.2010.10.009

Saccani E., Dilek Y., Marroni, M. \& Pandolfi, L. 2015: Continental margin ophiolites of Neotethys: Remnants of Ancient Ocean; Continent Transition Zone (OCTZ) lithosphere and their geochemistry, mantle sources and melt evolution patterns. Episodes, 38: 230249. https://doi.org/10.18814/epiiugs/2015/ v38i4/82418

Saccani, E., Dilek, Y. \& Photiades, A. 2017: Timeprogressive mantle-melt evolution and magma production in a Tethyan marginal sea: A case study of the Albanide-Hellenide ophiolites. Lithosphere, 10/1: 35-53. https://doi. org/10.1130/L602.1

Schefer, S., Egli, D., Missoni, S., Bernoulli, D., Fügenschuh, B., Gawlick, H.-J., Jovanovic, D., Krystyn, L., Lein, R., Schmid, S. \& Sudar, M. 2010: Triassic metasediments in the internal Dinarides (Kopaonik area, southern Serbia): Stratigraphy, paleogeographic and tectonic significance. Geologica Carpathica, 61: 89-109.

Scherreiks, R., Meléndez, G., BoudagherFadel, M., Fermeli, G. \& Bosence, D. 2014: Stratigraphy and tectonics of a time-transgressive ophiolite obduction onto the eastern margin of the Pelagonian platform from Late Bathonian until Valanginian time, exemplified in northern Evvoia, Greece. International Journal of Earth Sciences, 103/8: 2191-2216. https://doi.org/10.1007/s00531-014-1036-3

Schmid, M.S., Bernoulli, D., Fügenschuh, B., Matenco, L., Schefer, S., Schuster, R., Tischler, M. \& Ustaszewski, K. 2008: The Alps-Carpathians-Dinarides-connection: a correlation of tectonic units. Swiss Journal of Geosciences, 101/1: 139-183. https://doi. org/10.1007/S00015-008-1247-3

Schmid, M.S., Fügenschuh, B., Kounov, A., Matenco, L., Nievergelte, P., Oberhänsli, R., Pleugerg, J, Schefer, S., Schuster, R., Tomljenovići, B., Ustaszewski, K. \& van Hinsbergend, D.J.J. 2020: Tectonic units of the Alpine collision zone between Eastern Alps and western Turkey. Gondwana Research, 78: 308374. https://doi.org/10.1016/j.gr.2019.07.005

Siegesmund, S., Oriolo, S., Heinrichs, T., Basei, M.A.S., Nolte, N., Hüttenrauch, F. \& Schulz, B. 2018: Provenance of Austroalpine basement metasediments: tightening up Early Palaeozoic connections between 
peri-Gondwanan domains of central Europe and Northern Africa. International Journal of Earth Sciences, 107/6: 2293-2315. https:// doi.org/10.1007/s00531-018-1599-5

Spahić, D. \& Gaudenyi, T. 2018: Primordial geodynamics of Southern Carpathian - Balkan basements (Serbo-Macedonian Mass): Avalonian vs. Cadomian arc segments. Proceedings of the Geologists' Association, 130: 142-156. https://doi.org/10.1016/j.pgeola.2018.10.006

Spahić, D., Glavaš-Trbić, B., Đajić, S. \& Gaudenyi, T. 2018: Neoproterozoic - late Variscan geodynamics of the Drina Formation (DrinaIvanjica metamorphic basement). Geološki anali Balkanskoga poluostrva, 79/2: 57-68. https://doi.org/10.2298/GABP1802057S

Spahić, D., Glavaš-Trbić, B. \& Gaudenyi, T. 2019a: A hidden suture within the northern Paleotethyan margin: Paleogeographic/paleo-tectonic constraints on the Paleozoic 'Veles Series' (Vardar Zone, North Macedonia). Proceedings of the Geologists' Association, 130/6: 701-718.

Spahić, D., Gaudenyi, T. \& Glavaš-Trbić, B. 2019b: The Neoproterozoic - Paleozoic basement in the Alpidic Suupragetic/Kučaj units of eastern Serbia: a continuation of the Rheic Ocean? Acta Geologica Polonica, 69/4: 531548. https://doi.org/10.24425/agp.2019.126446

Spahić, D., Glavaš-Trbić, B., Gaudenyi, T. \& Poznanović-Spahić, M. 2019c: Paleozoic paleogeography and tectonic evolution of the Apulia/Adria microplate - is there a Variscan interference or not? In: Zbornik radova, 6 . knjiga sažetaka. II Kongres geologa Bosne i Hercegovine 2-4.10.2019. Udruženje / udruga geologa Bosne i Hercegovine: 42-46.

Spahić, D. \& Gaudenyi, T. 2019: Intraoceanic subduction of the northwestern Neotethys and geodynamic interaction with SerboMacedonian foreland: Descending vs. overriding neartrench dynamic constraints (East Vardar Zone, Jastrebac Mts., Serbia). Geološki anali Balkanskoga poluostrva, 80/2: 65-85.

Spahić, D. \& Gaudenyi, T. 2020a: Reconsidering late Paleozoic differences between the Jadar block and the Drina-Ivanjica unit. Geološki anali Balkanskoga poluostrva, 81/1: 1-9.

Spahić, D. \& Gaudenyi, T. 2020b: A few remarks on Triassic paleogeography and the geodynamic link betwwen the Dinarides and the Serbo-Macednian unit. Geološki anali Balkanskoga poluostrva, 81/1: 79-88.

Spahić, D. \& Gaudenyi, T. 2020c: The role of the 'Zvornik suture' for assessing the number of Neotethyan oceans: Surface - subsurface constraints on the fossil plate margin (Vardar Zone vs. Inner Dinarides). Geoloski anali Balkanskoga poluostrva, 81/2: 63-86.

Spahić, D., Glavaš-Trbić, B. \& Gaudenyi, T. 2020: The inception of the Maliac Ocean: Regional geological constraints on the western CircumRhodope belt (northern Greece). Marine and Petroleum Geology, 113: 104-133. https://doi. org/10.1016/j.marpetgeo.2019.104133

Spahić, D. \& Gaudenyi, T. 2021: On the Sava Suture Zone: Post-Neotethyan Oblique Subduction and the Origin of the Late Cretaceous MiniMagma Pools. Cretaceous Research, 131. https://doi.org/10.1016/j.cretres.2021.105062

Stampfli, G.M. \& Borel, G.D. 2002: A plate tectonic model for the Paleozoic and Mesozoic constrained by dynamic plate boundaries and restored synthetic oceanic isochrons. Earth Planetary Science Letters, 196: 17-33.

Stampfli, G.M., Borel, G.D., Cavazza, W., Mosar, J. \& Ziegler, P.A. 2001: Palaeotectonic and palaeogeographic evolution of the western Tethys and PeriTethyan domain (IGCP Project 369). Episodes, 24: 222-228. https:// doi.org/10.18814/epiiugs/2001/v24i4/001

Stampfli, G.M. \& Kozur, H.W. 2006: Europe from the Variscan to the Alpine cycles. In: Gee, D.G. \& Stephenson, R.A. (eds.): European Lithosphere Dynamics. Geological Society of London, Memoirs, 32: 57-82.

Šoster, A., Zavašnik, J., O'Sullivan, P., Herlec, U., Potočnik, B., Krajnc, B., Palinkaš, L., Zupančič, N. \& Dolenec, M. 2020: Geochemistry of Bashibos-Bajrambos Metasedimentary Unit, Serbo-Macedonian massif, North Macedonia: Implications for Age, Provenance and Tectonic Setting. Chemie der Erde - Geochemistry, 80/4:125664. https://doi.org/10.1016/j.chemer.2020.125664

Tomljenović, B., Csontos, L., Márton, E. \& Márton, P. 2008: Tectonic evolution of the northwestern Inner Dinarides as constrained by structures and rotation of Medvednica Mountains, North Croatia. In: Siegesmund, S., Fügenschuh, B. \& Froitzheim N. (eds.): Tectonic Aspects of the Alpine-DinarideCarpathian System. Geological Society of London, Special Publications, 298: 145-167.

Tremblay, A., Meshi, A., Deschamps, T. Goulet, F. \& Goulet, N. 2015: The Vardar zone as a suture for the Mirdita ophiolites, Albania: Constraints from the structural analysis of the Korabi-Pelagonia zone. Tectonics, 34/2: 352375. https://doi.org/10.1002/2014TC003807 
Trivić, B., Cvetković, V., Smiljanić, B. \& Gajić, R. 2010: Deformation pattern of the palaeozoic units of the Tethyan suture in the central Balkan Peninsula: a new insight from study of the Bukulja-Lazarevac Paleozoic unit Serbia. Ofioliti, 35/1: 21-32. https://doi. org/10.4454/ofioliti.v35i1.384

Vavvasis, I., Bono, A. de, Stampfli, G.M., Giorgis, D., Valloton, A. \& Amelin, Y. 2000: U-Pb and Ar-Ar geochronological data from the Pelagonian basement in Evia (Greece): geodynamic implications for the evolution of Paleotethys. Schweizerische mineralogische und petrographische Mitteilungen, 80: 21-33. https://doi.org/10.5169/seals-60948

Xypolias, P., Koukouvelas, I. \& Gernold, Z. 2008: Cenozoic tectonic evolution of northeastern Apulia: insights from a key study area in the Hellenides (Kythira, Greece). Zeitschrift der Deutschen Gesellschaft für Geowissenschaften, 159/3: 439-455. https:// doi.org/10.1127/1860-1804/2008/0159-0439

Zelić, M., D’Orazio, M., Malasoma, A., Marroni, M. \& Pandolfi, L. 2005: The Metabasites from the Kopaonik metamorphic complex, Vardar Zone, southern Serbia: remnants of the rifting-related magmatism of the Mesotethyan domain or evidence for Paleotethys closure in the Dinaric-Hellenic belt? Ofioliti, 30/2: 91-101.

Zelić, M., Marroni, M., Pandolfi, L. \& Trivić, B. 2010: Tectonic setting of the Vardar suture zone (Dinaric-Hellenic belt): the example of the Kopaonik area (southern Serbia). Ofioliti, 35/1: 33-47.
Zlatkin, O., Avigad, D. \& Gerdes, A. 2014: Peri-Amazonian provenance of the ProtoPelagonian basement (Greece), from zircon $\mathrm{U}-\mathrm{Pb}$ geochronology and $\mathrm{Lu}-\mathrm{Hf}$ isotopic geochemistry. Lithos, 184-187: 379-392. https:// doi.org/10.1016/J.LITHOS.2013.11.010

Zlatkin, O., Avigad, D. \& Gerdes, A. 2017: The Pelagonian terrane of Greece in the peri-Gondwanan mosaic of the Eastern Mediterranean: Implications for the geological evolution of Avalonia. Precambrian Research, 290: 163-183. https://doi.org/10.1016\%2Fj. precamres.2017.01.005

Zulauf, G., Dörr, W., Fisher-Spurlock, S.C., Gerdes, A., Chatzaras, V. \& Xypolias, P. 2015: Closure of the Paleotethys in the External Hellenides: Constraints from $\mathrm{U}-\mathrm{Pb}$ ages of magmatic and detrital zircons (Crete). Gondwana Research, 28/2: 642-667. https:// doi.org/10.1016/j.gr.2014.06.011

Zulauf, G., Dörr, W., Marko, L. \& Krahl, A. 2018: The late Eo-Cimmerian evolution of the external Hellenides: constraints from microfabrics and $\mathrm{U}-\mathrm{Pb}$ detrital zircon ages of Upper Triassic (meta)sediments (Crete, Greece). International Journal of Earth Sciences, 107: 2859-894. https://doi.org/10.1007/ s00531-018-1632-8

Žák, J., Svojtkab, M., Hajnáa, J. \& Ackerman, L. 2020: Detrital zircon geochronology and processes in accretionary wedges. EarthScience Reviews, 207: 103-214. https://doi. org/10.1016/j.earscirev.2020.103214 